\title{
IMPROVING WATER PRODUCTIVITY OF BEANS THROUGH DOUBLE RIDGE FURROW IRRIGATION METHOD
}

\author{
Elmetwalli, A. H.* and M. M. Ibrahim**
}

\begin{abstract}
Food security and water resources are in danger as a result of water scarcity and there is a need to produce more crop yields with less water. Consequently, adopting new efficient irrigation methods is crucially important to sustain population growth. This study compared the effects of applying two different surface irrigation methods (traditional furrow and double ridge furrow irrigation methods) on yield, water productivity of dry beans in sandy loam soils taking two irrigation intervals into consideration. Different irrigation treatments were compared in terms of beneficial water use and economical water productivity for the two irrigation methods. Comparing the results obtained from different treatments, the double ridge furrow method is advantageous in comparison with traditional furrow irrigation in terms of water saving. It was obvious that double ridge furrow method can at least save 40-50\% of water which can directly expand the cultivated area in the Nile Delta and Valley. As a result of saving water, beans water productivity increased by 41 and $34 \%$ over the traditional furrow method. The results therefore showed that double ridge furrow method can be a robust irrigation method to increase water productivity by applying less irrigation water while having higher yields.
\end{abstract}

Keywords: improving, surface, irrigation, double, ridge, furrow, irrigation, water, productivity and costs

\section{INTRODUCTION}

ontinues increase in world's population with limited water resources particularly in arid and semi arid regions requires increasing water productivity. Therefore the progressive need for more food to sustain rapidly population growth with limited water resources forces farmers to use more efficient irrigation systems to maximize crop productivity.

\footnotetext{
* Assoc. Prof., Agric. Eng. Dept., Fac. of Agric., Tanta Univ.

** Lecturer, Agric. Eng. Dept., Fac. of Agric., Al-Mansoura Univ.
} 
Water is considered one of the main factors limiting crop production of various crops and therefore water application method is crucial for obtaining maximum grain yield. Availability of water rather than land is the main obstacle on agricultural production in arid and semi arid regions and also the most important factor limiting plant yield and performance worldwide (Sezen et al., 2011). Limited water resources and growing need for water will reduce the availability of water. Additionally, increasing water pumping cost and low efficiency of traditional irrigation systems are among the main reasons that prompt many farmers to apply less water to crops than that required to obtain maximum yield (Craciun and Craciun, 1999). Irrigation water management attempts to increase economic return while using less water or less energy (Sidhu et al., 2008).

Green bean (Phaseolus Vulgaris L.) is a major crop cultivated in many countries in arid and semi arid regions. In hot weather conditions large amounts of water are needed to produce beans and other agricultural crops as a result of high evapotranspiration. Accomplishing maximum crop productivity per unit of applied water has become critical since costs for irrigation and limited water resources increase (Hunsaker et al., 1998). Efetha et al. (2011) concluded that available water should be used as efficiently as possible by applying irrigation management practices which enhance increased grain yield and water conservation.

One way to increase traditional surface furrow irrigation efficiency is to develop the furrow irrigation management technique to decrease water losses. Previous studies used different techniques to improve surface furrow irrigation such as surge flow irrigation (Unlu et al., 2007), alternate furrow irrigation (Kang et al., 2000 and Weber et al., 2006 and Thind et al., 2010), cutback flow (Humpherys 1978) and deficit irrigation (Geerts and Raes, 2009 and Okwany et al., 2012).

Surface furrow irrigation is the most commonly used method in the Nile Delta and Valley. The method causes great water losses to deep percolation and surface runoff that lead to low irrigation efficiency. Additionally most farmers in Egypt over irrigate their crops particularly the fields at the beginning of irrigation canal network. Efficient irrigation methods are therefore essential in the Nile Valley and Delta to increase 
water productivity and also can be a step forward to expand the cultivated area. Under good management practices, double ridge furrow irrigation method and similar techniques can result in remarkable water saving with less effect on yield production. In this context, this research aimed to enhance water productivity and water use efficiency of beans crop under Egyptian conditions.

\section{MATERIALS AND METHODS}

\section{Site description and agronomic practices}

A field experiment was undertaken in Elnasr village, Bohaira Province, Egypt (latitude of 30.93 and longitude of 29.92). The average temperature in the study site over spring season is about $26{ }^{\circ} \mathrm{C}$. Rainfall is very low over this period of time. Soil samples were collected prior to the experiment to determine soil physical and chemical analysis. Soil samples were taken from two different depths (0-15 and 15-30). Samples were oven dried, sieved $(2 \mathrm{~mm})$ and soil paste extract was prepared for various analyses. The soil texture at this site is a sandy loam soil with low nitrogen concentration having $15.8 \%$ clay, $4.8 \%$ silt and $79.4 \%$ sand). Table 1 shows both chemical and physical properties of the experimental soil.

Table (1) Chemical and physical analysis of soil at the experimental site

\begin{tabular}{|c|c|c|c|c|c|c|c|c|c|c|c|}
\hline \multirow{2}{*}{$\begin{array}{c}\text { Depth, } \\
\mathrm{cm}\end{array}$} & $\mathrm{EC}$, & $\mathrm{pH}$ & \multicolumn{5}{|c|}{ Cations, meq/1 } & \multicolumn{5}{|c|}{ Anions, meq/l } & \multirow{2}{*}{ Texture } \\
\cline { 4 - 12 } & $\mathrm{dS} / \mathrm{m}$ & & $\mathrm{Ca}$ & $\mathrm{Mg}$ & $\mathrm{Na}$ & $\mathrm{K}$ & $\mathrm{Co}_{3}$ & $\mathrm{HCO}_{3}$ & $\mathrm{Cl}$ & $\mathrm{SO}_{4}$ & \\
\hline $0-30$ & 1.48 & 7.6 & 11.7 & 1.18 & 7.31 & 1.94 & 0.3 & 8.2 & 9.5 & 4.13 & Sandy loam \\
\hline $30-60$ & 1.35 & 7.7 & 9.7 & 1.98 & 6.15 & 1.11 & 0.1 & 7.5 & 8.2 & 3.14 & Loam \\
\hline
\end{tabular}

Beans seeds were planted on March $20^{\text {th }}$ over 2016 spring growing at a rate of $120 \mathrm{~kg} \mathrm{ha}^{-1}$. All experimental plots were irrigated to ensure high germination percentage, and they irrigated again a week after planting. When soil became dry, plants in all plots were thinned to just one plant per hole to accomplish the recommended plant density. Nitrogen fertilizer in the form of ammonium nitrate was applied as recommended in two equal doses at $45 \mathrm{~kg} \mathrm{ha}^{-1}$ each. The first dose of nitrogen fertilizer was applied concurrent with the third irrigation and the second dose was applied at the fourth irrigation for each treatment. Four different treatments with three replicates were assigned for this research study. The 
experimental area was divided into small plots with an area of $15^{*} 15 \mathrm{~m}$. A $2 \mathrm{~m}$ buffer was left without planting to avoid overlapping between different treatments. The distance between furrows was $0.60 \mathrm{~m}$ in case of using traditional furrow method while the distance was $1.2 \mathrm{~m}$ for the double ridge furrow method. When the crop reached the maturation, each plot was harvested manually for threshing. The three replicates of each treatment were taken in consideration to get the mean for means comparison.

\section{The studied treatments were:}

$\mathrm{F}_{10}$ : traditional furrow method with 10 days irrigation interval $\mathrm{F}_{15}$ : traditional furrow method with 15 days irrigation interval $\mathrm{DF}_{10}$ : double ridge furrow method with 10 days irrigation interval and $\mathrm{DF}_{15}$ : double ridge furrow method with 15 days irrigation interval

\section{Application rate of irrigation water}

Water was delivered to different plots through a concrete channel and the discharge rate was measured by the help of a rectangular weir of $0.4 \mathrm{~m}$ width. The total amount of irrigation water delivered was calculated using the following formula:

$\mathrm{Q}=\frac{2}{3} \mathrm{C}_{\mathrm{d}} \sqrt{ } 2 \mathrm{~g} \mathrm{~B} \mathrm{H} \mathrm{H}^{1.5}$

Where $Q$ is the amount of water $\left(\mathrm{m}^{3} \mathrm{~s}^{-1}\right), \mathrm{B}$ is the width of weir $(\mathrm{m}), \mathrm{C}_{\mathrm{d}}$ is the discharge coefficient of weir (taken 0.95 ) and $\mathrm{H}$ is the water head over the weir. A stop watch was used to estimate the time required to irrigate each plot to identify the total amount of water for every treatment. Care was taken to ensure constant head over the weir base.

\section{Water productivity}

Water productivity is defined as the weight of grains produced from one cubic meter of water and can be calculated according to Rodrigues and Pereira (2009) as follows:

$$
P=\frac{Y}{D}
$$

Where $\mathrm{P}$ is water productivity in $\mathrm{Mg}$ per every cubic meter of water, $\mathrm{Y}$ is the total grain yield obtained from one hectare in $\mathrm{Mg} \mathrm{ha} \mathrm{h}^{-1}, \mathrm{D}$ is the amount of water applied in $\mathrm{m}^{3} \mathrm{ha}^{-1}$.

\section{Cost analysis}


The net return of any agricultural production is fundamentally important for countries suffering limited natural resources especially water resources. Inputs and net return of various irrigation treatments was investigated to choose the optimum and efficient irrigation method. The total cost of different irrigation treatment was calculated taking into account the rent of water pumping machine (9hp). In this study the rent was LE15 per hour and irrigation cost $\left(\mathrm{LE} \mathrm{Mg}^{-1}\right)$ was calculated using the following equation

Irrigation cost $=\frac{C}{Y}$

Where $\mathrm{C}$ is the total cost for irrigation over the growing season $\left(\mathrm{LE} \mathrm{ha}^{-1}\right)$, $\mathrm{Y}$ is the grain yield $\left(\mathrm{Mg} \mathrm{ha}^{-1}\right)$.

\section{Profit cost ratio}

Profit cost ratio is an indicator of the return of each pound invested and is based on the net profit and total cost which is calculated as follows:

Profit cost ratio $=$ net profit/total cost

Where net profit is the difference between total cost and total income of the crop obtained.

\section{Statistical analysis}

Data were subjected to statistical analysis using Minitab v15. Data were checked for normality using Anderson-Darling method with a 95\% significance level. Different between various treatments were checked through Duncan's multiple range test at $5 \%$ probability level. Additionally, treatment means were compared for statistical significance using a least significant difference (LSD) test. Simple linear regression analysis was used to derive regression equations to predict beans grain yield.

\section{RESULTS AND DISCUSSIONS}

Effect of irrigation method and irrigation intervals on beans grain yield

Data listed in Table 2 shows the effect of irrigation technique and irrigation interval on beans grain yield. The highest grain yield of $2269 \mathrm{~kg}$ ha $^{-1}$ was recorded with $\mathrm{F}_{10}$ treatment while the lowest grain yield of 1784 $\mathrm{kg}$ ha ${ }^{-1}$ was recorded with $\mathrm{DF}_{15}$. The statistical analysis showed non significant differences between means of treatments. It is obvious that the traditional furrow method of 10 days irrigation interval produced the 
highest grain yield which may have been a result of more available water in the root zone that enhance the metabolic process via healthy root system and makes it easier for plants to uptake water and nutrients. Larger root system enables plants to acquire and fulfill water requirements. $\mathrm{DF}_{10}$ treatment produced more grain yield than $\mathrm{F}_{15}$ (19\% more) which can be attributed to supply sufficient available water to plants. From the above mentioned results, it can be concluded that irrigation by double ridge furrow can save more water that leads to enlarge the cultivated land area through the utilization of efficient techniques.

Table (2) Beans productivity as affected by both irrigation method and irrigation interval

\begin{tabular}{cccccc}
\hline \multirow{2}{*}{$\begin{array}{c}\text { Irrigation } \\
\text { treatment }\end{array}$} & \multicolumn{3}{c}{ Grain yield Mg ha } & Mean & $\begin{array}{c}\text { Applied } \\
\text { water, } \\
\mathrm{m}^{3} \mathrm{ha}^{-1}\end{array}$ \\
\hline $\mathrm{F}_{10}$ & 2177 & 2279 & 2351 & $2269_{\mathrm{a}}$ & 7973 \\
$\mathrm{~F}_{15}$ & 2210 & 1869 & 1689 & $1922_{\mathrm{ab}}$ & 6218 \\
$\mathrm{DF}_{10}$ & 1961 & 2066 & 2259 & $2095_{\mathrm{ab}}$ & 4862 \\
$\mathrm{DF}_{15}$ & 1763 & 1875 & 1716 & $1784_{\mathrm{ab}}$ & 3667 \\
\hline
\end{tabular}

$\mathrm{F}_{10}$, traditional furrow irrigation with 10 days irrigation intervals; $\mathrm{F}_{15}$, traditional furrow irrigation with 15 days irrigation intervals; $\mathrm{DF}_{10}$, double ridge furrow with 10 days irrigation intervals and $\mathrm{DF}_{15}$, double ridge furrow with 15 days irrigation intervals

\section{Association between amounts of water and water productivity}

As a result of using double ridge furrow irrigation the amount of irrigation water decreased as shown in Table 3. The results demonstrated a remarkable significant decrease in the amount of water used in different treatments. The highest percent of water save $54.8 \%$ was recorded with the double ridge method with 15 days interval $\left(\mathrm{DF}_{15}\right)$ when compared with the traditional furrow method $\left(\mathrm{F}_{15}\right) . \mathrm{DF}_{10}$ also showed a significant decrease in water consumption in comparison to $\mathrm{F}_{15}$ since it saved water by $39 \%$. The results obviously demonstrated that DF technique needs less water to produce more or less the same productivity of traditional furrow method that can lead to expand the cultivated area. Less time was required for both $\mathrm{DF}_{10}$ and $\mathrm{DF}_{15}$ and resultantly less water pumping cost. Double ridge furrow of both investigated irrigation intervals was more advantageous than traditional furrow method in terms of evapotranspiration since the wetted area is smaller. 
Water productivity was significantly affected by the method of applying irrigation water (furrow and double furrow methods). Both DF irrigation treatments showed positive significant effects on water productivity values since the highest water productivity value of $0.49 \mathrm{~kg} \mathrm{~m}^{-3}$ was recorded with $\mathrm{DF}_{15}$ followed by $\mathrm{DF}_{10}$ that produced $0.43 \mathrm{~kg} \mathrm{~m}^{-3}$. Traditional furrow method of both tested intervals produced less water productivity in comparison to double ridge furrow method (Table 3 and Fig. 1). The results showed that DF15 increased water productivity by 41 and $34 \%$ over $\mathrm{F} 10$ and $\mathrm{F} 15$, respectively. These increases in water productivity could be attributed to less applied water. Broadly, double ridge furrow technique can give a step forward to increase utilization efficiency of water and therefore increase water productivity.

Table (3) Water productivity, water applied and water saved as affected by various investigated treatments (irrigation methods and intervals)

\begin{tabular}{|c|c|c|c|c|c|}
\hline \multirow{2}{*}{$\begin{array}{l}\text { Irrigation } \\
\text { treatment }\end{array}$} & Water applied & \multicolumn{2}{|c|}{ Water saved } & \multirow{2}{*}{$\begin{array}{l}\text { Grain yield, } \\
\mathrm{Mg} \mathrm{ha}^{-1}\end{array}$} & \multirow{2}{*}{$\begin{array}{c}\text { Water } \\
\text { productivity, } \\
\mathrm{kg} / \mathrm{m}^{3}\end{array}$} \\
\hline & $\mathrm{m}^{3} \mathrm{ha}^{-1}$ & $\mathrm{~m}^{3} \mathrm{ha}^{-1}$ & $\%$ & & \\
\hline $\mathrm{F}_{10}$ & 7973 & - & - & 2269 & 0.29 \\
\hline $\mathrm{F}_{15}$ & 6218 & 1755 & 22.0 & 1922 & 0.31 \\
\hline $\mathrm{DF}_{10}$ & 4862 & 3111 & 39.0 & 2095 & 0.43 \\
\hline $\mathrm{DF}_{15}$ & 3667 & 4306 & 54.8 & 1784 & 0.49 \\
\hline
\end{tabular}

$\mathrm{F}_{10}$, traditional furrow irrigation with 10 days irrigation intervals; $\mathrm{F}_{15}$, traditional furrow irrigation with 15 days irrigation intervals; $\mathrm{DF}_{10}$, double ridge furrow with 10 days irrigation intervals and $\mathrm{DF}_{15}$, double ridge furrow with 15 days irrigation intervals

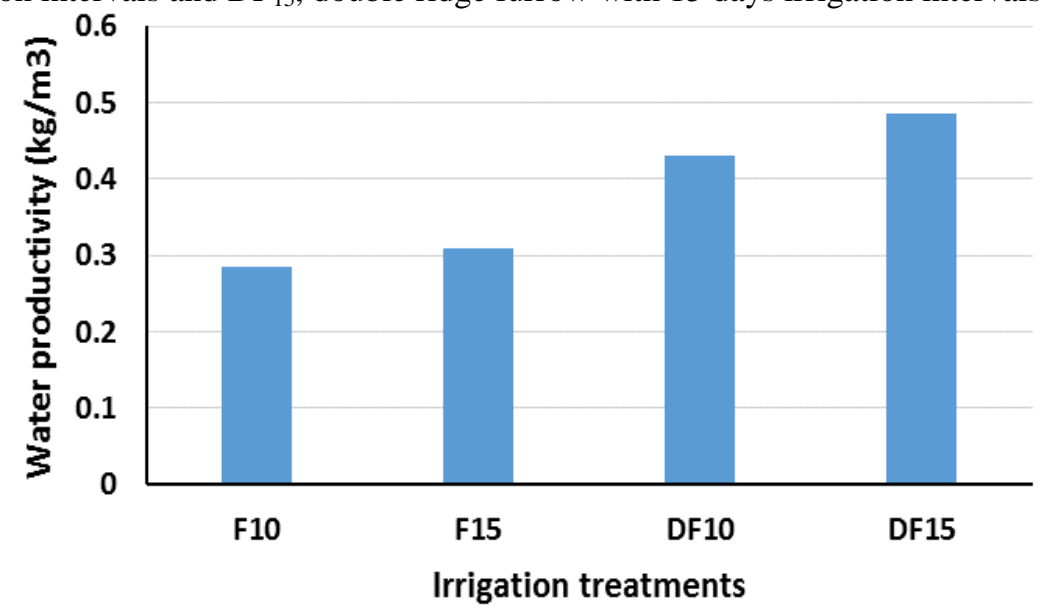

Fig. (1) Beans water productivity under the effect of irrigation water treatments (irrigation method and interval) 


\section{Economic evaluation}

Green bean production costs were calculated taking into account all production inputs including seeds cost, labor cost, plowing cost, fertilization, thinning, and irrigation cost. The results were evaluated from the economical point of view considering production cost and investment. The results presented in Fig. 2 that pumping less water decreased the total cost of irrigation in the double ridge irrigation treatments particularly DF15 whilst pumping larger amounts of water as in F10 treatment increased the total cost of irrigation over the whole growing season. Table 4 detailed that among different treatments, $\mathrm{DF}_{10}$ produced the second highest total income (18855 $\mathrm{LE} \mathrm{ha}^{-1}$ ) and also produced the second highest net profit of LE 9085 per hectare. Regarding the cost of irrigation per every ton of grains, it is clear that the double ridge method decreased irrigation cost per every ton of bean grains. $\mathrm{DF}_{15}$ and $\mathrm{DF}_{10}$ decreased irrigation cost per every ton by 57 and $43 \%$, respectively comparing to the traditional furrow method, $F_{10}$, which can be attributed to less pumping time for double ridge treatments. Profit cost ratio of $\mathrm{F}_{10}$ was recorded the highest value $(0.99)$ followed by $\mathrm{DF}_{10}(0.93)$ as depicted in Fig. 3.

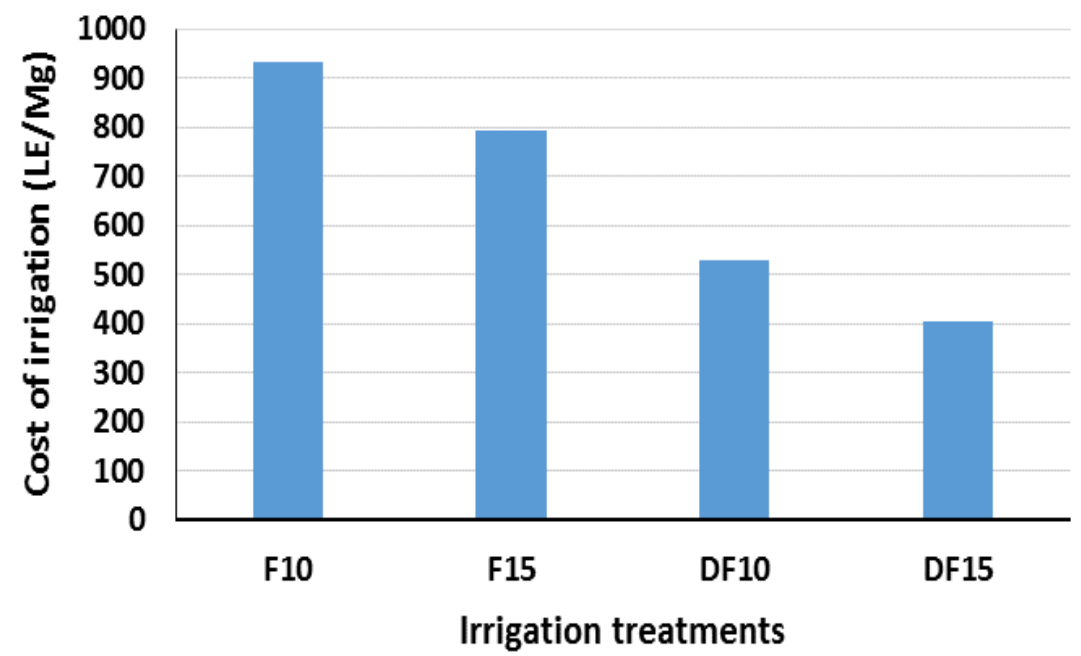

Fig. (2) The effect of irrigation water treatments (irrigation method and interval) on irrigation cost 
Table (4) Inputs and outputs costs of beans crop production as influenced by furrow and double ridge furrow irrigation methods and irrigation intervals

\begin{tabular}{|c|c|c|c|c|c|}
\hline \multirow{2}{*}{$\begin{array}{l}\text { Inputs and } \\
\text { outputs }\end{array}$} & \multirow{2}{*}{ Cost, LE } & \multicolumn{4}{|c|}{ Irrigation treatment } \\
\hline & & $\mathrm{F}_{10}$ & $\mathrm{~F}_{15}$ & $\mathrm{DF}_{10}$ & $\mathrm{DF}_{15}$ \\
\hline \multirow{10}{*}{ Inputs } & Land rent & 2380 & 2380 & 2380 & 2380 \\
\hline & Plowing & 380 & 380 & 380 & 380 \\
\hline & Seed price & 1070 & 1070 & 1070 & 1070 \\
\hline & Fertilization & 2045 & 2045 & 2045 & 2045 \\
\hline & Pesticides & 950 & 950 & 950 & 950 \\
\hline & Labor & 1310 & 1310 & 1310 & 1310 \\
\hline & Irrigation cost & 990 & 640 & 495 & 320 \\
\hline & Harvesting & 665 & 665 & 665 & 665 \\
\hline & Threshing & 475 & 475 & 475 & 475 \\
\hline & Total & 10265 & 9915 & 9770 & 9595 \\
\hline \multirow{5}{*}{ Outputs } & Grain yield, $\mathrm{Mg} \mathrm{ha}^{-1}$ & 2269 & 1922 & 2095 & 1784 \\
\hline & Total income, LE ha ${ }^{-1}$ & 20421 & 17298 & 18855 & 16056 \\
\hline & Net profit, LE ha ${ }^{-1}$ & 10156 & 7383 & 9085 & 6461 \\
\hline & Cost of irrigation $\mathrm{LEMg}^{-1}$ & 932.2 & 792 & 528.5 & 403 \\
\hline & Profit cost ratio & 0.99 & 0.74 & 0.93 & 0.67 \\
\hline
\end{tabular}

$\mathrm{F}_{10}$, traditional furrow irrigation with 10 days irrigation intervals; $\mathrm{F}_{15}$, traditional furrow irrigation with 15 days irrigation intervals; $\mathrm{DF}_{10}$, double ridge furrow with 10 days irrigation intervals and $\mathrm{DF}_{15}$, double ridge furrow with 15 days irrigation intervals

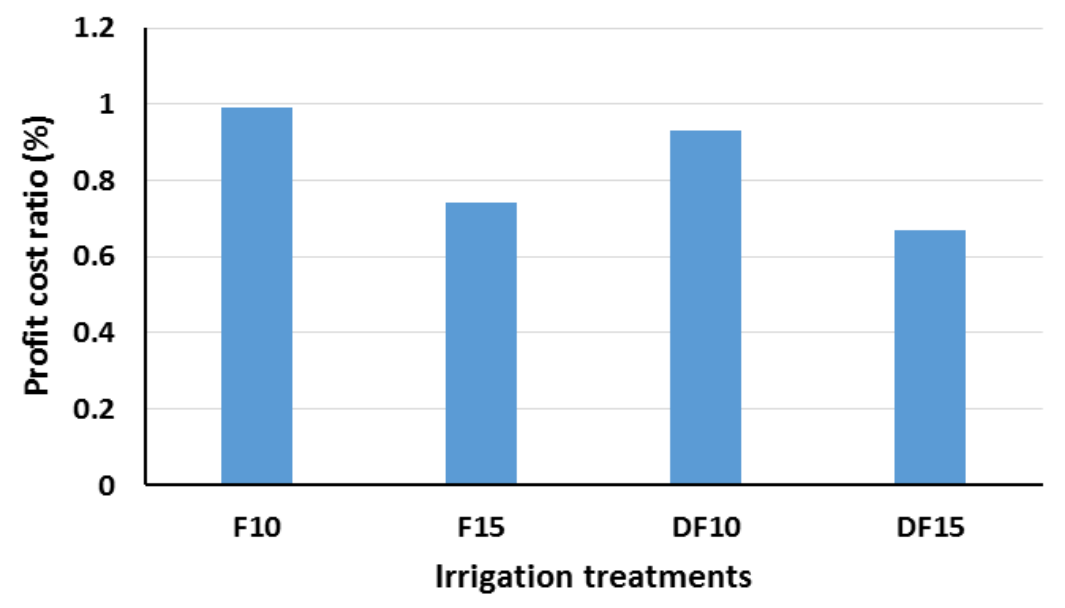

Fig. (3) Profit cost ratio under both irrigation method and interval

\section{CONCLUSION}

The effectiveness of double ridge furrow irrigation method for improving surface furrow irrigation efficiency was investigated in the present study. From the obtained results it can be concluded that double ridge furrow 
method is a possible way to save water and thus increase water productivity. The results further demonstrated that water was saved by $54.8 \%$ when using the double ridge method comparing to the traditional furrow method which can be used to increase the cultivated area in newly reclaimed regions. In conclusion, this research obviously revealed that under limited water resources, the double ridge irrigation method can serve as a reliable irrigation technique to increase water productivity. Additionally, it is strongly recommended that water saving by $40-50 \%$ would be advantageous if the strategy is to expand and double the cultivated area. Double ridge furrow method is therefore a reliable irrigation method that can at least double the cultivated area of beans in the Nile Valley and newly reclaimed areas.

\section{REFERENCES}

Craciun, I. and Craciun, M. (1999). Water and nitrogen use efficiency under limited water supply for maize to increase land productivity. In: Kirda, C. Moutonnet, P., Hera, C. and Nielsen, D.R. (Eds), Crop yield response to deficit irrigation. Kluwer Academic Publisher, the Netherlands, pp. 87-94.

Efetha, A.; Harms, T. and M. Bandara (2011). Irrigation management practices for maximizing seed yield and water use efficiency of Othello dry bean (Phaseolus vulgaris L.) in southern Alberta, Canada. Irri. Sci., 29: 103-113.

Geerts, S. and D. Raes (2009). Deficit irrigation as an on-farm strategy to maximize crop water productivity in dry areas. Agric. Water Manag., 96: 1275-1284.

Humpherys, A.S. (1978). Improving farm irrigation systems by automation. In: Proceeding of the international commission on Irrigation and Drainage, $10^{\text {th }}$ Congress, Athens, Greece, pp. 35 .

Hunsaker, D.J.; A.J. Clemmens and Fangmeier, D.D. (1998). Cotton response to high frequency surface irrigation. Agric. Water Mang., 37: 55-74.

Kang, S. Z.; P. Shi; Y.H. Pan; Z.S. Liang; X.T. Hu and J. Zhang (2000). Soil water distribution, uniformity and water use efficiency under alternate furrow irrigation in arid areas. Irri. Sci., 19: 181-190.

Okwany, R. O.; Peters, T. R.; Ringer, K. L.; Walsh, D. B. and Rubio, M. (2012). Impact of sustained deficit irrigation on spearmint (Mentha 
spcata L.) biomass production, oil yield and oil quality. Irri. Sci. 30: 213-219.

Rodrigues, G.C. and Pereira, L.S. (2009). Assessing economic impacts of deficit irrigation as related to water productivity and water costs. Biosystems Eng., 103: 536-551.

Sezen, S.M. Yazar, A.; Kapur, B. and Tekin, S. (2011). Comparison of drip and sprinkler irrigation stratigies on sunflower seed and oil yield and quality under Mediterranean climatic conditions. Agric. Water mang., 98: 1153-1161.

Sidhu, A.S.; Mahal, S.S.; Mahey, R.K. and Kumar, K. (2008). Root density, water use efficiency, harvest index and seed yield of hybrid canola (Brassica napus) as influenced by different irrigation schedules and nitrogen levels. Environ. Ecol., 26 (1A): 261-265.

Thind, H. S.; Buttar, G. S. and Aujla (2010). Yield and water use efficiency of wheat and cotton under alternate furrow and check basin irrigation with canal and tube well water in Punjab, India. Irri. Sci. 28: 489-496.

Unlu, M.; R. Kanber; S. Onder; M. Sezen; K. Diker; B. Ozekici and M. Oylu (2007). Cotton yields under different furrow irrigation management techniques in the southeastern Anatolia Project (GAP) area, Turkey. Irri. Sci., 26: 35-48.

Weber, H.A.; C.A. Madramootoo; M. Bourgault; M.G. Horst; G. Stulina and D.L. Smith (2006). Water use efficiency of common bean and green gram grown using alternate furrow and deficit irrigation. Agric. Water Mang., 86: 259-268.

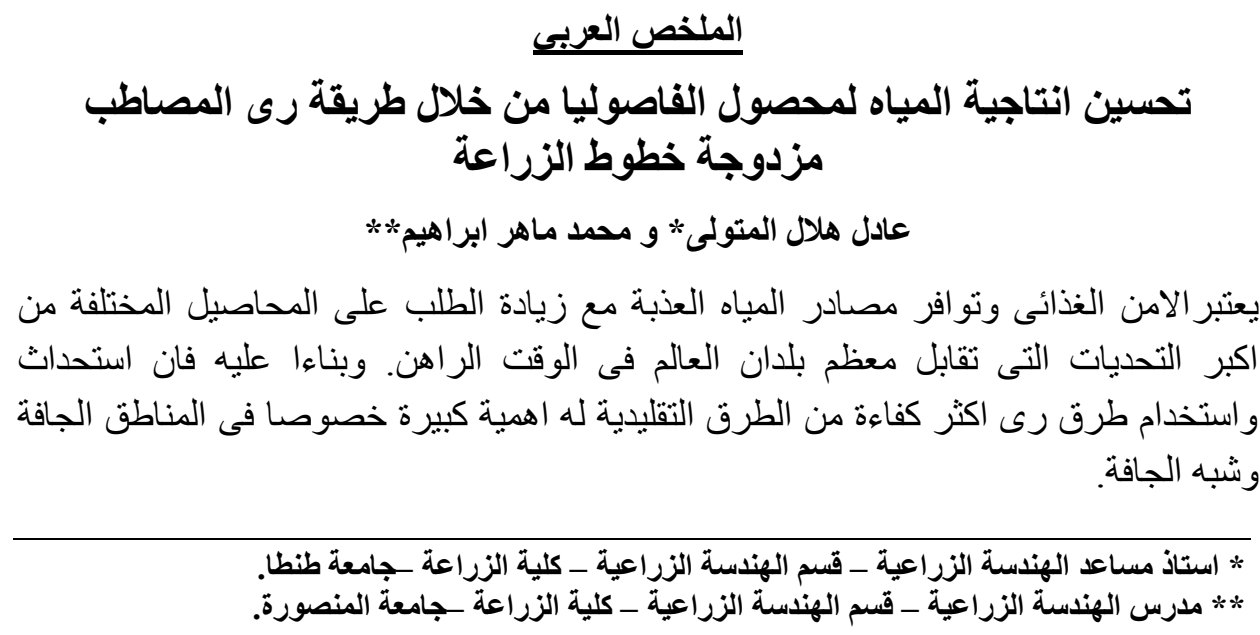


ومن هذا المنظور فان هذه الدراسة أجريت على محصول الفاصوليا خلال موسم الربيع لعام

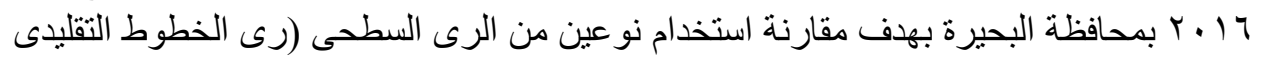

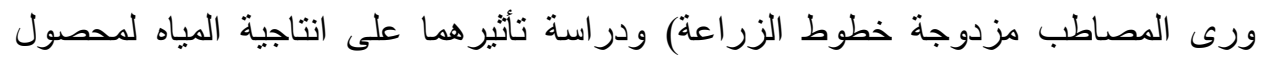
الفاصوليا فى الار اضىى الخفيفة. وكانت معاملات الدر اسة هي كالتالى:

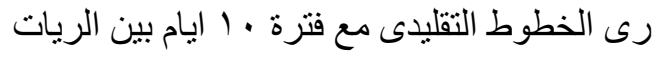

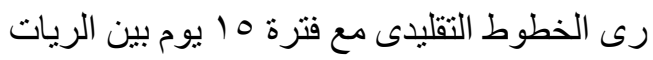

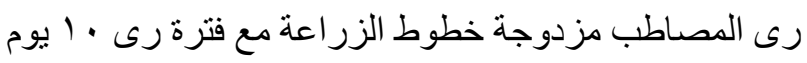

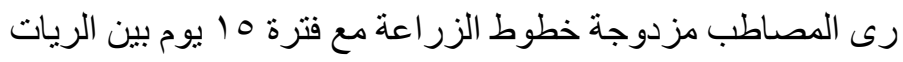

لقد تم تقدير كمية المياه المستخدمة طو ال موسم الزر اعة وتقدير الانتاجيـة للمعاملات المختلفة ثم

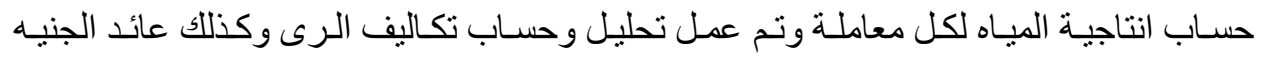
المستثمر لكل معاملة واظهرت الدراسة النتائج التالية:

استخدام طريقة رى المصساطب بخطوط مزدوجـة لمحصـول الفاصسوليا ادى الى توفير

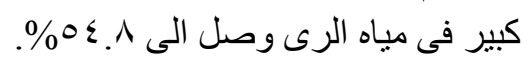

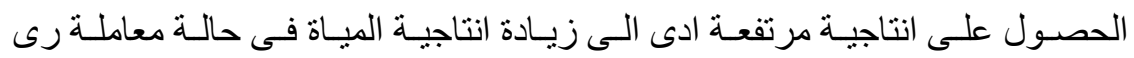

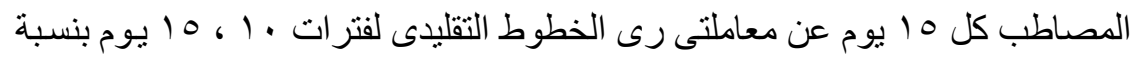

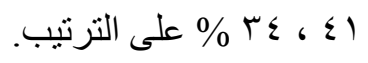

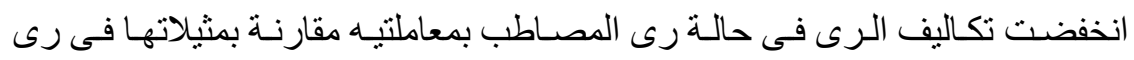
الخطوط التقليدى.

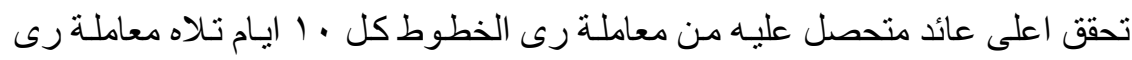

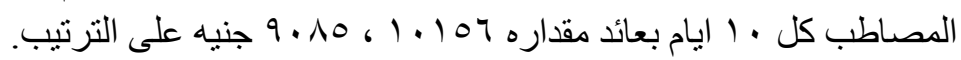

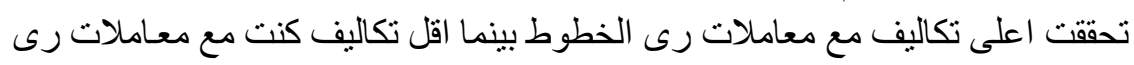

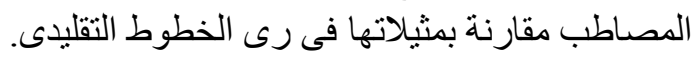

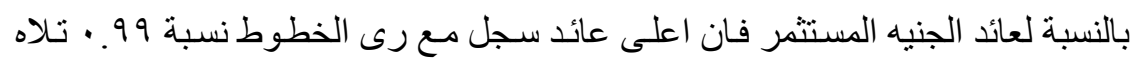

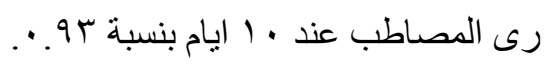

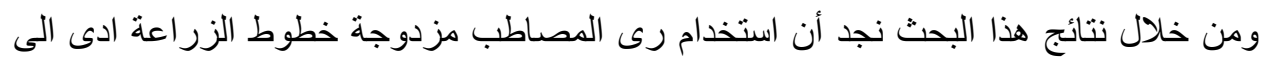

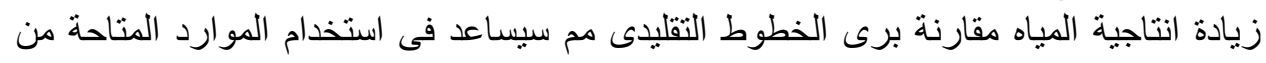

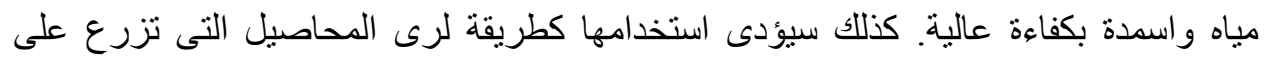
خطوط الى مضاعفة المساحة المنزر عة. 